\title{
U.S. International Transactions in 1997
}

Lois E. Stekler, of the Board's Division of International Finance, prepared this article. Virginia Carper and Clarke Fauver provided research assistance.

The U.S. current account deficit widened further in 1997, reaching $\$ 166$ billion. U.S. imports of goods continued to exceed exports by a substantial margin (table 1). However, goods trade accounted for only a small part of the deterioration in the current account balance last year. The shift of investment income from positive to negative (the first time since 1914) was the major contributing factor; it reflected the cumulative effect of deficits in the current account that have persisted since 1982 and the balancing net capital inflows. The financial crises in Asia in the second half of 1997 visibly affected U.S. capital flows but influenced the U.S. current account in only a limited way in that year. Their effect on the U.S. current account is likely to be more apparent in 1998 .

The current account deficit in 1997 was almost as large as the record deficit in 1987; relative to the size of the U.S. economy, however, it was substantially smaller (2 percent of gross domestic product in 1997 versus 3.6 percent in 1987).

\section{MAJOR ECONOMIC INFLUENCES ON U.S. INTERNATIONAL TRANSACTIONS}

The U.S. current and capital accounts in 1997 were shaped by a wide variety of factors. These included U.S. economic growth and exchange rate develop- ments, the financial crises affecting many developing economies in Asia, and rates of economic growth in other developing and industrial countries.

\section{U.S. Economic Growth and Exchange Rate Developments}

The U.S. economy grew at a robust pace in 1997 (table 2). Aggregate demand (including the demand for imports of goods and services) was strong, and corporate profits (including the profits of U.S. affiliates of foreign companies) were high. Inflation nonetheless remained subdued, partly because of decreases in the prices of imported goods as a result of the appreciation of the dollar against many currencies and because of declines in prices on international commodity markets.

From December 1996 to December 1997 the dollar gained 12 percent in nominal terms against an average (weighted by multilateral trade weights) of the currencies of the other Group of Ten (G-10) countries (chart 1). The dollar appreciated in terms of the other G-10 currencies during the first half of 1997, as the continuing strength of U.S. economic activity raised expectations of further tightening of U.S. monetary conditions. Also, the dollar tended to rise in terms of the German mark and other continental European currencies because of concerns about the implications of the transition to the European Economic and Monetary Union and perceptions that monetary policy was not likely to tighten significantly in prospec-

1. U.S. current account balance, 1992-97

Billions of dollars

\begin{tabular}{|c|c|c|c|c|c|c|c|}
\hline Item & 1992 & 1993 & 1994 & 1995 & 1996 & 1997 & $\begin{array}{l}\text { Change, } \\
1996 \text { to } 1997\end{array}$ \\
\hline Current account balance & -56.4 & -90.8 & -133.5 & -129.1 & -148.2 & -166.4 & -18.2 \\
\hline $\begin{array}{l}\text { Trade in goods and services, net } \\
\text { Goods, net } \ldots \ldots \ldots \ldots \ldots \ldots \ldots \\
\text { Services, net } \ldots \ldots \ldots \ldots \ldots \ldots \ldots\end{array}$ & $\begin{array}{r}-39.2 \\
-96.1 \\
56.9\end{array}$ & $\begin{array}{r}-72.3 \\
-132.6 \\
60.3\end{array}$ & $\begin{array}{r}-104.4 \\
-166.2 \\
61.8\end{array}$ & $\begin{array}{r}-101.9 \\
-173.6 \\
71.7\end{array}$ & $\begin{array}{r}-111.0 \\
-191.2 \\
80.1\end{array}$ & $\begin{array}{r}-113.6 \\
-198.9 \\
85.3\end{array}$ & $\begin{array}{r}-2.6 \\
-7.7 \\
5.2\end{array}$ \\
\hline $\begin{array}{l}\text { Investment income, net ... } \\
\text { Portfolio investment, net } \\
\text { Direct investment, net .. }\end{array}$ & $\begin{array}{r}18.0 \\
-33.6 \\
51.6\end{array}$ & $\begin{array}{r}19.7 \\
-36.0 \\
55.7\end{array}$ & $\begin{array}{r}9.7 \\
-41.0 \\
50.8\end{array}$ & $\begin{array}{r}6.8 \\
-53.2 \\
60.0\end{array}$ & $\begin{array}{r}2.8 \\
-63.9 \\
66.8\end{array}$ & $\begin{array}{r}-14.3 \\
-82.0 \\
67.7\end{array}$ & $\begin{array}{r}-17.1 \\
-18.1 \\
.9\end{array}$ \\
\hline Unilateral transfers, net & -35.2 & -38.1 & -38.8 & -34.0 & -40.0 & -38.5 & 1.5 \\
\hline
\end{tabular}

Note. In this and the tables that follow, components may not sum to totals

Source. U.S. Department of Commerce, Bureau of Economic Analysis, U.S because of rounding. international transactions accounts. 
2. Change in real GDP in the United States and abroad, 1995-97

Percentage change, year over year

\begin{tabular}{|c|c|c|c|}
\hline Country & 1995 & 1996 & $1997^{1}$ \\
\hline United States & 2.0 & 2.8 & 3.8 \\
\hline Total foreign & 2.7 & 3.6 & 4.2 \\
\hline Industrial countries' index ${ }^{2}$ & 2.3 & 2.2 & 2.9 \\
\hline Canada & 2.2 & 1.2 & 3.8 \\
\hline Western Europe ....... & 2.7 & 2.2 & 2.9 \\
\hline Japan ................ & 1.4 & 4.1 & .9 \\
\hline Developing countries' index ${ }^{3}$ & 3.5 & 6.0 & 6.2 \\
\hline Asia & 7.7 & 6.9 & 6.0 \\
\hline Latin America & -3.4 & 4.5 & 6.4 \\
\hline Mexico ..... & -6.2 & 5.1 & 7.0 \\
\hline Other Latin America & 2.4 & 3.2 & 5.0 \\
\hline
\end{tabular}

NotE. Aggregate measures are chain-weighted by moving bilateral shares in U.S. exports of nonagricultural merchandise.

1. Data for 1997 are partly estimated.

2. The industrial countries' index covers Australia and New Zealand in addition to Canada, Japan, and Western Europe. The index for Western Europe comprises Austria, Belgium, Denmark, Finland, France, Germany, Greece, Ireland, Italy, the Netherlands, Norway, Portugal, Spain, Sweden, Switzerland, Turkey, and the United Kingdom.

3. The developing countries in the index for Asia are the Peoples Republic of China, Hong Kong, Indonesia, Korea, Malaysia, the Philippines, Singapore, Taiwan, and Thailand. The countries in "Other Latin America" are Argentina, Brazil, Chile, and Venezuela.

SOURCE. Various national sources.

tive member countries. In the first half of the year, the dollar fluctuated against the Japanese yen in response to varying indicators of the strength of the Japanese expansion. But in the second half, the yen depreciated in response to evidence of faltering economic activity and perceptions of fragility in the Japanese financial sector. The perceptions of fragility were heightened by concerns about the negative effect on Japan of the financial crises elsewhere in Asia. As will be discussed in greater detail, the dollar also

1. Weighted-average exchange rate of the dollar against currencies of the Group of Ten, 1990-97

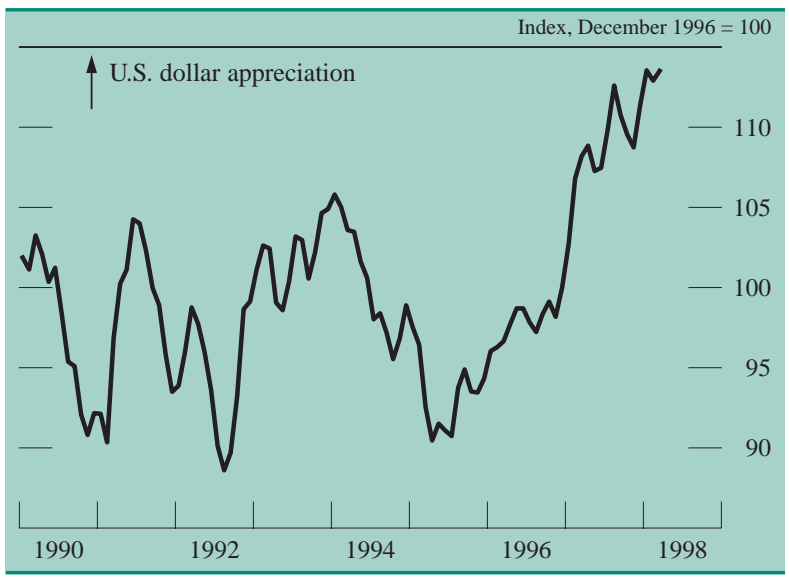

NoTE. The weight for each of the ten countries is the 1972-76 average world trade of that country divided by the average world trade of all ten countries combined. Besides the United States, the Group of Ten consists of Belgium, Canada, France, Germany, Italy, Japan, the Netherlands, Sweden, Switzerland, and the United Kingdom. The data are monthly. appreciated strongly against the currencies of developing countries in the second half of 1997.

Robust U.S. economic growth and tax collections moved the federal government budget close to balance in 1997. In general, reducing government dissaving would tend to move the current account toward balance as well; however, the current account deficit has been widening. In terms of national income accounting identities, the growing U.S. current account deficit (and the related national income concept, negative net foreign investment) must reflect a growing gap between domestic investment and saving (chart 2). However, the statistical discrepancy in the national income accounts has shifted from a large positive value to a large negative value in recent years, obscuring whether increases in investment, or reductions in private savings, or both have been the counterpart to the growing current account deficits. In any case, the inflow of foreign savings, which has financed part of U.S. investment over the past decade and a half, has raised productive capacity relative to what it would have been but has required ongoing payments of investment income to foreigners.

\section{Asian Financial Crises}

In July, strong downward pressure on the Thai baht marked the beginning of a series of Asian financial crises. Severe financial market pressures spread to other East Asian countries-most notably Indonesia and South Korea. These pressures appeared to have been triggered mainly by market concerns over substantial external deficits, possibly overvalued exchange rates, weak financial systems, sizable foreign-currency-denominated indebtedness, and government policy responses that were widely viewed as inadequate. The financial market pressures persisted despite the initiation of several financial assistance agreements led by the International Monetary Fund.

Several countries experienced sharp depreciations in their currencies. Between the end of June and the end of December, the Thai baht, Korean won, and Indonesian rupiah lost about half their value; the Indonesian rupiah continued to fall sharply in early 1998 (chart 3). The financial market turmoil in East Asia spread to Hong Kong and, to a lesser extent, Taiwan. However, the peg of the Hong Kong currency to the U.S. dollar has been successfully maintained, and the depreciation of the Taiwan dollar has been relatively small.

The turmoil in Asian financial markets was accompanied by sharp declines in stock prices, increases in interest rates, sharply reduced credit availability, 
2. U.S. investment, savings, and current account balance as a percentage of GDP, 1980-97

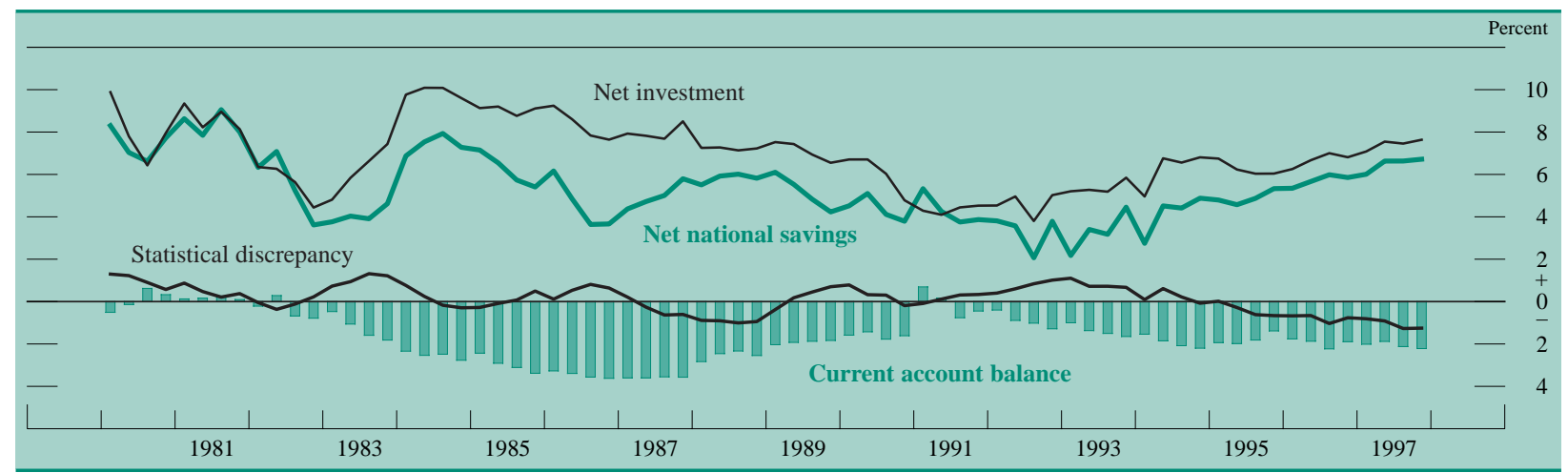

Note. The statistical discrepancy is from the national income and product Source. U.S. Department of Commerce, Bureau of Economic Analysis, accounts (NIPA). The data are quarterly. NIPA, and U.S. international transaction accounts.

heightened uncertainty, and, in some cases, somewhat tighter fiscal policies in connection with international support packages. As a consequence, economic activity slowed markedly in several Asian developing economies in the second half of 1997; growth between the second and fourth quarters of 1997 for these economies as a group averaged only about $23 / 4$ percent at a seasonally adjusted annual rate, or less than half the 6 percent or more of earlier periods (table 2). This slowdown is expected to continue into 1998.

\section{Economic Growth in Other Developing and Industrial Countries}

Financial markets in some Latin American countries also came under pressure as the Asian crises led investors to reassess the riskiness of their exposures. However, despite considerable pressure, both the Brazilian exchange rate regime and the peg of the Argentine peso to the dollar held. In Brazil, high domestic interest rates and the tightening of macroeconomic policy to support the exchange rate weakened domestic demand toward the end of the year. In Mexico, the recovery of economic activity from the recession following the 1994-95 crisis continued, although the peso weakened. On average, economic growth in Latin America (weighted by shares in U.S. exports) was robust in 1997 (table 2).

Economic growth in the industrial countries firmed in 1997 (table 2). Growth in Canada was particularly robust, and most of the European countries also showed some improvement. Japan was a notable exception, as the growth of real GDP stalled partly in response to sizable fiscal contraction. In addition, as mentioned earlier, crises in many of Japan's Asian trading partners in the second half of the year weak- ened the outlook for external demand and heightened concerns about the fragility of Japan's financial sector.

\section{DEVELOPMENTS IN TRADE IN GOODS AND SERVICES}

In 1997 the overall U.S. trade deficit rose slightly in nominal terms from its 1996 level (table 1). A small increase in the deficit in trade in goods was almost matched by the increase in the surplus in services trade. However, because of differing price developments among the trade components, the trade deficit in terms of chained (1992) dollars continued to grow, and net exports subtracted about 0.6 percentage point from the growth of U.S. GDP between the fourth quarter of 1996 and the fourth quarter of 1997.

3. Dollar exchange rates for selected foreign currencies, January 1997-March 1998

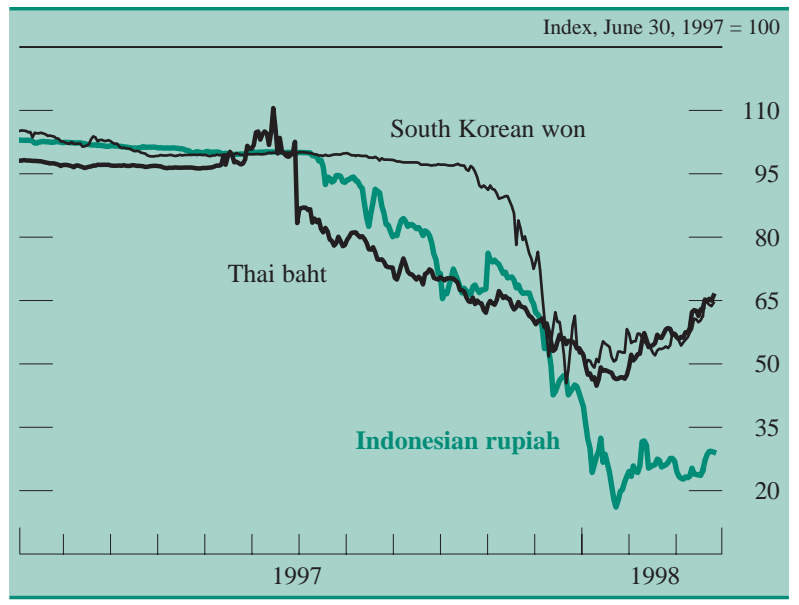

Note. Dollars per unit of foreign currency. The data are daily. 
3. U.S. international trade in goods and services, 1995-97

Billions of dollars

\begin{tabular}{|c|c|c|c|c|c|}
\hline \multirow{2}{*}{ Item } & \multirow{2}{*}{1995} & \multirow{2}{*}{1996} & \multirow{2}{*}{1997} & \multicolumn{2}{|c|}{ Dollar change } \\
\hline & & & & 1995 to 1996 & 1996 to 1997 \\
\hline Balance on goods and services & -102 & -111 & -114 & -9.1 & -2.7 \\
\hline Exports of goods and services & 795 & 849 & 932 & 54.2 & 82.7 \\
\hline Services................... & 219 & 237 & 253 & 18.1 & 16.4 \\
\hline Goods .. & 576 & 612 & 678 & 36.2 & 66.2 \\
\hline Agricultural products . & 57 & 62 & 58 & 4.3 & -3.1 \\
\hline Nonagricultural goods & 519 & 551 & 620 & 31.9 & 69.3 \\
\hline Capital goods ...... & 234 & 253 & 294 & 19.0 & 41.1 \\
\hline Aircraft and parts $\ldots \ldots \ldots \ldots \ldots$ & 26 & 31 & 41 & 5.0 & 10.4 \\
\hline Computers, peripherals, and parts & 40 & 44 & 49 & 4.0 & 5.6 \\
\hline Semiconductors ................ & 34 & 36 & 39 & 1.6 & 3.0 \\
\hline Other capital goods & 134 & 143 & 165 & $\begin{array}{l}1.0 \\
8.4\end{array}$ & 22.1 \\
\hline Consumer goods ..... & 64 & 70 & 77 & $\begin{array}{l}.4 .4 \\
6.0\end{array}$ & 7.4 \\
\hline Automotive products & 62 & 65 & 73 & 3.0 & 8.4 \\
\hline Industrial supplies .... & 146 & 148 & 158 & 2.0 & 10.1 \\
\hline Other nonagricultural exports & 13 & 15 & 17 & 1.9 & 2.3 \\
\hline Imports of goods and services & 897 & 960 & 1,045 & 63.4 & 85.3 \\
\hline Services......$\ldots \ldots \ldots$ & 147 & 157 & 168 & 9.6 & 11.3 \\
\hline Goods.. & 749 & 803 & 877 & 53.8 & 74.1 \\
\hline Oil and products & 56 & 73 & 72 & 16.7 & -.6 \\
\hline Non-oil goods . & 693 & 731 & 805 & 37.1 & 74.7 \\
\hline Capital goods .... & 221 & 229 & 254 & 8.0 & 25.2 \\
\hline Aircraft and parts & 11 & 13 & 17 & $\begin{array}{l}.00 \\
2.0\end{array}$ & 3.6 \\
\hline Computers, peripherals, and parts & 56 & 62 & 70 & 6.0 & $\begin{array}{l}.0 \\
8.1\end{array}$ \\
\hline Semiconductors .................. & 39 & 37 & 37 & -2.0 & -.1 \\
\hline Other capital goods . & 115 & 117 & 131 & 2.0 & 13.6 \\
\hline Consumer goods ..... & 160 & 171 & 193 & 11.0 & 21.9 \\
\hline Automotive products & 124 & 129 & 141 & 5.0 & 11.7 \\
\hline Industrial supplies .. & 129 & 137 & 145 & 8.3 & 8.0 \\
\hline Foods and other non-oil imports & 59 & 64 & 72 & 4.8 & 7.9 \\
\hline
\end{tabular}

Note. Changes in this and subsequent tables may differ from those calculated from the data shown in the tables because of rounding. international transactions accounts.

\section{Exports}

The value of U.S. exports of goods and services grew $\$ 83$ billion in 1997, or about 10 percent, an acceleration from the 7 percent gain in 1996 (table 3). Exports of goods grew more rapidly than exports of services.

\section{Goods Exports}

Exports of goods to Latin America rose more than 20 percent, and the growth to Canada and Western Europe was also strong (table 4). In contrast, exports to Japan declined slightly, and those to developing countries in Asia grew moderately, although more rapidly than in 1996. The financial crises in Asian developing economies had little noticeable effect on U.S. exports of goods in 1997.

Capital goods accounted for substantially more than half of the increase in the value of U.S. exports of goods in 1997 (table 3). Smaller increases were reported for a broad range of other products, including industrial supplies, automotive products, and consumer goods. Although the quantity of agricultural exports remained high, their value declined, as agri- cultural prices fell from elevated levels reached early in the year.

Given the loss of export price competitiveness associated with the appreciation of the dollar against many currencies over the past two years (chart 4), the strength of U.S. exports of goods in 1997 was somewhat surprising. Sustained economic growth

4. U.S. exports of goods to its major trading partners, 1995-97

Billions of dollars

\begin{tabular}{|c|c|c|c|c|}
\hline Importing region & 1995 & 1996 & 1997 & $\begin{array}{c}\text { Percentage } \\
\text { change, } \\
1996 \text { to } 1997\end{array}$ \\
\hline Total & 576 & 612 & 678 & 10.8 \\
\hline Industrial countries ${ }^{1}$ & 335 & 351 & 383 & \\
\hline Canada & 128 & 135 & 152 & 12.8 \\
\hline Western Eurc & 132 & 137 & 153 & 11.4 \\
\hline Japan & 63 & 66 & 65 & -2.0 \\
\hline Developing countries $^{2}$ & 241 & 261 & 295 & 13.1 \\
\hline Asia .................. & 130 & 135 & 145 & 6.9 \\
\hline Latin America & 96 & 109 & 134 & 22.7 \\
\hline Mex & 46 & 57 & 71 & 25.6 \\
\hline Other Latin America & 50 & 52 & 62 & 19.8 \\
\hline
\end{tabular}

1. The industrial countries include Australia and New Zealand in addition to Canada, Western Europe, and Japan.

2. The developing countries include Eastern Europe and Africa in addition to Asia and Latin America.

SouRCE. U.S. Department of Commerce, Bureau of Economic Analysis, U.S. international transactions accounts. 
4. Relative prices of exports and imports, 1989-97

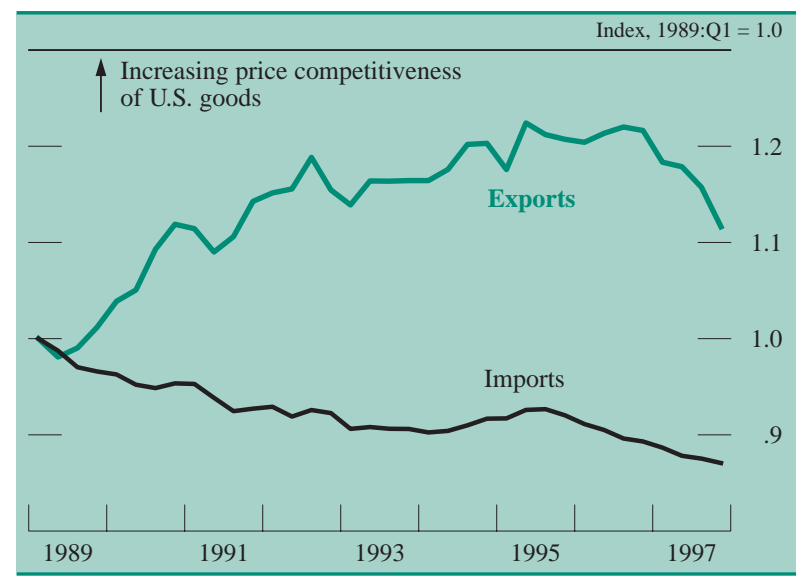

NotE. For exports, the index is the ratio of foreign prices to U.S. export prices of nonagricultural products, excluding computers and semiconductors. For imports, the index is the ratio of U.S. import prices of non-oil imports, excluding computers and semiconductors, to the U.S. GDP deflator. The data are quarterly.

in important U.S. export markets, particularly Latin America, Canada, and Western Europe, partly countered the loss of price competitiveness. However, even taking strong foreign economic growth into account, U.S. exports increased more than would have been expected based on estimated income and price elasticities. U.S. exporters probably benefited from the trend in Mexico and other Latin American countries away from policies that sheltered domestic producers from international competition.

The growth in the value of U.S. exports was largely the result of the rapid growth in the quantity of goods exported rather than increases in prices (table 5).

5. Change in the quantity of U.S. exports and imports, 1995-97

Percentage change, year over year

\begin{tabular}{|c|c|c|c|}
\hline Type of export or import & 1995 & 1996 & 1997 \\
\hline All exports & 11.1 & 8.3 & 12.4 \\
\hline Services & 7.4 & 5.5 & 5.1 \\
\hline Goods. & 12.6 & 9.5 & 15.4 \\
\hline Agricultural products & 11.5 & -1.8 & 1.6 \\
\hline Nonagricultural goods & 12.7 & 10.8 & 16.9 \\
\hline Computers, peripherals, and parts & 46.5 & 46.2 & 50.1 \\
\hline Semiconductors $\ldots \ldots \ldots \ldots \ldots$ & 76.8 & 47.1 & 40.5 \\
\hline Other nonagricultural goods . & 6.7 & 5.7 & 12.7 \\
\hline All imports & 8.9 & 9.1 & 14.2 \\
\hline Services & 6.1 & 5.5 & 9.5 \\
\hline Goods & 9.5 & 9.9 & 15.1 \\
\hline Oil and products & -1.6 & 7.6 & 5.1 \\
\hline Non-oil goods & 10.5 & 10.1 & 16.2 \\
\hline Computers, peripherals, and parts & 42.5 & 33.4 & 44.0 \\
\hline Semiconductors ............... & 74.4 & 63.5 & 57.1 \\
\hline Other non-oil goods ..... & 5.3 & 5.4 & 12.0 \\
\hline
\end{tabular}

Note. Quantities are measured in chained (1992) dollars.

SourcE. U.S. Department of Commerce, national income and product accounts.
Growth in quantity was rapid not just for computers and semiconductors (for which price indexes adjusted for technological change and quality improvements-hedonic price indexes-declined rapidly) but also for other nonagricultural exports.

\section{Services Exports}

Exports of private services grew $\$ 16$ billion, or about 7 percent (table 6). The largest dollar increase was in "other private services," a catchall category that included particularly large increases in U.S. receipts for business, professional, and technical services, and financial services. U.S. receipts of royalties and license fees and exports of "other private services" largely reflect the U.S. comparative advantage in services that depend heavily on technological expertise and contribute significantly to the net surplus in services trade enjoyed by the United States. Exports of traditional services like travel, passenger fares, and transportation continued to account for more than half of U.S. services exports in 1997, but the growth of these traditional exports was moderated by the appreciation of the dollar and the resulting decline in U.S. price competitiveness.

\section{Imports}

The value of U.S. imports of goods and services grew \$85 billion in 1997 (about 9 percent), somewhat faster than the rate in 1996 (table 3). As on the export side, imports of goods grew more rapidly than imports of services. Imports were spurred by strong economic growth in the United States in 1997 together with a decline in the price competitiveness of U.S. goods (chart 4), largely as the result of the appreciation of the dollar against many currencies.

\section{Oil Imports}

Although the volume of oil imports increased about 5 percent from 1996 to 1997, their value fell slightly because of a 5 percent decline in the average price. Several factors contributed to the fall in oil prices and, at the time of this writing, have induced a further decline from levels prevailing at the end of 1997.

Changes in the prices of imported oil have tended to mirror changes in spot oil prices (West Texas intermediate) with a lag of several weeks (chart 5). Spot prices had risen quite sharply during the second half of 1996 , from $\$ 18.54$ per barrel in June to $\$ 25.39$ 
6. Service transactions, 1994-97

Billions of dollars

\begin{tabular}{|c|c|c|c|c|c|}
\hline Item & 1994 & 1995 & 1996 & 1997 & $\begin{array}{l}\text { Change, } \\
1996 \text { to } 1997\end{array}$ \\
\hline Service transactions, net & 62 & 72 & 80 & 85 & 5 \\
\hline Exports of private services & 184 & 204 & 221 & 237 & 16 \\
\hline Travel ................... & 58 & 63 & 70 & 74 & 4 \\
\hline Passenger fares $\ldots . .$. & 17 & 19 & 21 & 22 & 1 \\
\hline Other transportation . & 25 & 27 & 27 & 28 & 1 \\
\hline Royalties and license fees & 23 & 27 & 30 & 30 & 0 \\
\hline Other private services .... & 61 & 67 & 74 & 83 & 9 \\
\hline Imports of private services & 123 & 135 & 143 & 154 & 11 \\
\hline Travel ........... & 44 & 46 & 49 & 52 & 3 \\
\hline Passenger fares .... & 13 & 14 & 16 & 17 & 1 \\
\hline Other transportation & 27 & 28 & 28 & 30 & 1 \\
\hline Royalties and license fees & 6 & $\begin{array}{r}20 \\
7\end{array}$ & $\begin{array}{r}20 \\
7\end{array}$ & 8 & 0 \\
\hline Other private services .... & 33 & 39 & 43 & 48 & 5 \\
\hline U.S. government and military services, net & 0 & 2 & 2 & 2 & 0 \\
\hline
\end{tabular}

SouRCE. U.S. Department of Commerce, Bureau of Economic Analysis, U.S. international transactions accounts.

in December. Refiners-uncertain about the availability of crude oil supplies from Iraq and concerned about the effect that such supplies might have on the price of oil-tended to keep their stocks low.

With the oil industry operating at minimal, just-intime inventory levels, oil prices reacted quite strongly to unanticipated shocks. Two such events in 1996the delay in the startup of several North Sea fields and economic activity in the United States that was

\section{Oil prices per barrel, 1985-97}

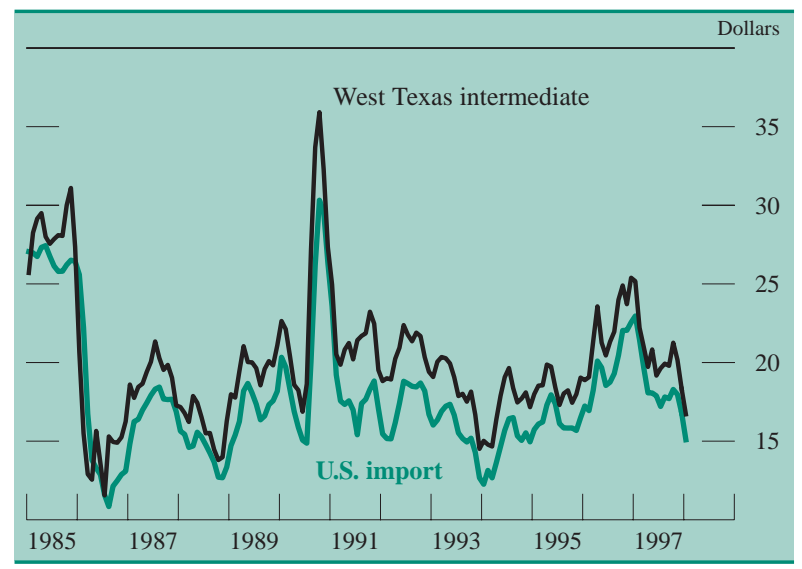

Note. The data are monthly.

Source. Petroleum Intelligence Weekly, various issues; and U.S. Department of Commerce, Bureau of Economic Analysis. stronger than anticipated-drove oil prices up. Once Iraq began producing oil for export at the beginning of 1997, spot oil prices fell sharply, from an average of $\$ 25.17$ per barrel in January to $\$ 19.72$ in April. Spot prices traded in a range of $\$ 19$ to $\$ 20$ per barrel during the remainder of the year. Oil import prices averaged about $\$ 18.63$ per barrel in 1997 , about a dollar below the average for 1996. Spot prices fell during January and February of 1998 as a result of several developments: Saudi Arabia, Kuwait, and the United Arab Emirates raised production in line with increases in their OPEC quota; warmer-than-normal weather from El Niño softened demand for home heating oil; and the economic turmoil in East Asia reduced shipments to those emerging economies.

The quantity of oil imports rose from an average of 9.4 million barrels per day in 1996 to 9.9 million in 1997 (table 7). An increase in U.S. consumption in the range of 0.4 million barrels per day accounted for most of the increase in the quantity of imports, as U.S. production has been little changed over the past four years.

\section{Non-Oil Imports}

The value of non-oil imports of goods increased \$75 billion in 1997 (about 10 percent), up substan-

7. U.S. oil consumption, production, and imports, selected years, 1980-97 Millions of barrels per day

\begin{tabular}{|c|c|c|c|c|c|c|}
\hline Item & 1980 & 1985 & 1994 & 1995 & 1996 & 1997 \\
\hline Consumption & 17.1 & 15.7 & 17.7 & 17.7 & 18.2 & 18.6 \\
\hline Production & 10.8 & 11.2 & 9.4 & 9.4 & 9.5 & 9.4 \\
\hline
\end{tabular}

SouRCE. U.S. Department of Energy, Energy Information Administration. 
8. U.S. imports of non-oil goods from its major trading partners, 1995-97

Billions of dollars

\begin{tabular}{|c|c|c|c|c|}
\hline Exporting region & 1995 & 1996 & 1997 & $\begin{array}{c}\text { Percentage } \\
\text { change, } \\
1996 \text { to } 1997\end{array}$ \\
\hline Total & 693 & 731 & 805 & 10.2 \\
\hline Industrial countries $^{1}$ & 408 & 421 & 456 & 8.2 \\
\hline Canada & 137 & 146 & 159 & 8.5 \\
\hline Western Europe & 142 & 155 & 170 & 9.7 \\
\hline Japan .......... & 123 & 115 & 121 & 5.5 \\
\hline Developing countries ${ }^{2}$ & 286 & 309 & 349 & 12.9 \\
\hline Asia $\ldots \ldots \ldots \ldots \ldots$ & 189 & 199 & 222 & 11.5 \\
\hline Latin America .. & 87 & 99 & 115 & 15.6 \\
\hline Mexico ....... & 57 & 67 & 78 & 16.7 \\
\hline Other Latin America & 30 & 32 & 36 & 13.0 \\
\hline
\end{tabular}

1. See table 4 , note 1 .

2. See table 4 , note 2 .

SourCE. U.S. Department of Commerce, Bureau of Economic Analysis, U.S. international transactions accounts.

tially from 1996 (table 3). Large increases in imports of consumer goods as well as capital goods accounted for much of the increase; imports of automotive products also rose more than they had in 1996.

The industrial countries continued to account for more than half of U.S. non-oil imports in 1997. However, imports from developing countries continued to grow much faster than average (table 8). Growth of imports from Mexico was particularly strong, a development perhaps reflecting the continuing effect of the North American Free Trade Agreement on the pattern of U.S. trade.

As with exports, the increase in the value of nonoil imports largely reflected growth in quantity rather

6. Nominal dollar exchange rate indexes, 1995-97

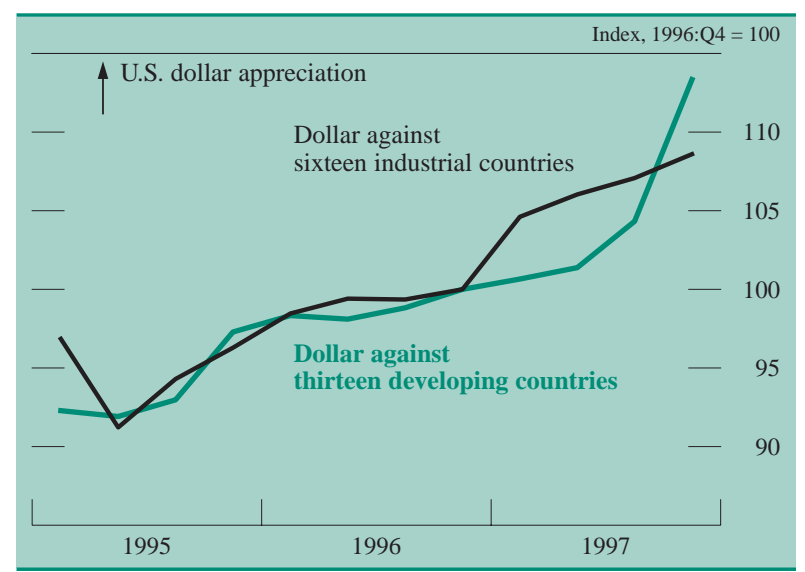

NoTE. The indexes are weighted by bilateral import shares, excluding oil, computers, and semiconductors. The industrial countries are Australia, Austria, Belgium, Canada, Finland, France, Germany, Ireland, Italy, Japan, the Netherlands, Portugal, Spain, Sweden, Switzerland, and the United Kingdom. The developing countries are Argentina, Brazil, Chile, Mexico, China, Hong Kong, Indonesia, Korea, Malaysia, the Philippines, Singapore, Taiwan, and Thailand. The data are quarterly. than higher prices (table 5). Rapid quality improvements in computers and semiconductors continued to push down their hedonic price indexes. However, the prices of core imports (goods imports excluding oil, computers, and semiconductors) also fell-about $3 / 4$ percent between the fourth quarter of 1996 and the fourth quarter of 1997; declines in world commodity prices played a role, but appreciation of the dollar was also a factor. The nominal exchange rate of the dollar against the currencies of thirteen developing economies (weighted by bilateral import shares excluding oil, computers, and semiconductors) appreciated 14 percent between the fourth quarter of 1996 and the fourth quarter of 1997; against the currencies of sixteen industrial countries, the dollar appreciated almost 9 percent during the same period (chart 6).

\section{Services Imports}

Imports of private services rose $\$ 11$ billion in 1997 , an increase of more than 7 percent (table 6). Although imports of services that depend on technical expertise are much smaller than exports of such services, "other private services" accounted for about half the increase in value of service imports. U.S. expenditures on travel abroad also increased.

\section{DEVELOPMENTS IN THE NONTRADE CURRENT ACCOUNT}

The two major components of the current account other than trade in goods and services are net unilateral transfers and net investment income (table 1).

\section{Net Unilateral Transfers}

Net unilateral transfers include government grant and pension payments as well as net private transfers to foreigners. The deficit on unilateral transfers fell slightly from the 1996 level, to \$39 billion. The 1996 level had been unusually large because of the deferring of transfers to 1996 during the budget impasse and government shutdown at the end of 1995 (table 1).

\section{Net Investment Income}

Net investment income is the difference between the amount that U.S. residents earn on their direct and 
7. U.S. net international investment: Position and income, 1980-97

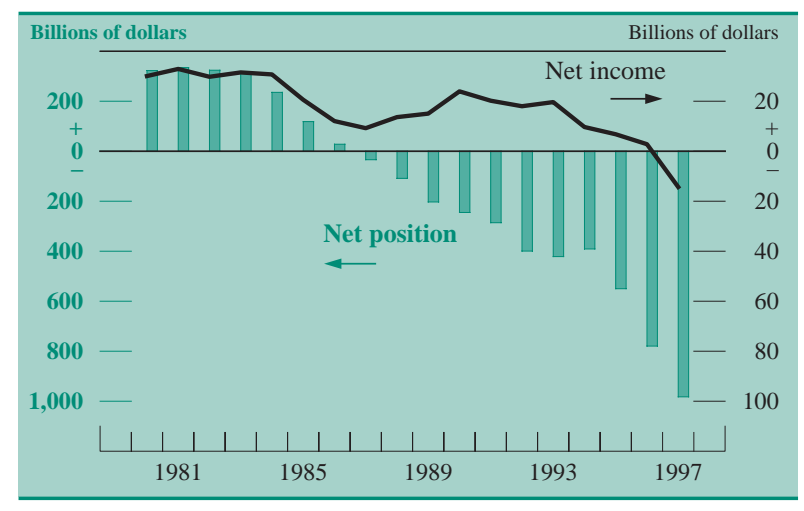

Note. The net position for each year is the average of the year-end positions for the current and previous years. The year-end position for 1997 was constructed by adding the recorded net portfolio and direct investment flows during 1997 to the recorded year-end position for 1996. The net position excludes U.S. gold holdings and foreign holdings of U.S. currency.

SourCE. U.S. Department of Commerce, Bureau of Economic Analysis; and Federal Reserve Board.

portfolio investments abroad (receipts) and the amount that foreigners earn on their direct and portfolio investments in the United States (payments). ${ }^{1}$ Revised data indicate that net investment income turned negative in 1997 for the first time since 1914 (table 9). The data on investment income were revised in light of the results of the Benchmark Survey of U.S. Ownership of Foreign Long-Term Securities, discussed later. As a result of large and persistent U.S. current account deficits over the past decade and a half, foreign assets in the United States have grown more rapidly than U.S. assets abroad. However, net investment income remained positive (chart 7) long after the net investment position became negative because foreign direct investment in the United States has earned a far lower rate of return than U.S. direct investment abroad.

\section{Net Direct Investment Income}

Net direct investment income reported by U.S. and foreign corporations on Department of Commerce surveys rose little in 1997, as the dollar increase in payments about matched the increase in receipts (table 9).

The growth of income on U.S. direct investment abroad in 1997 was the product of both strong eco-

1. An investment is considered direct if a single owner acquires 10 percent or more of the voting equity in a company. All other U.S. claims on foreigners or foreign claims on the United States are included in the other category-portfolio investment.
9. U.S. investment income, 1994-97

Billions of dollars

\begin{tabular}{|c|c|c|c|c|}
\hline Item & 1994 & 1995 & 1996 & 1997 \\
\hline Investment income, net & 10 & 7 & 3 & -14 \\
\hline Direct investment income, net & 51 & 60 & 67 & 68 \\
\hline Receipts. & 71 & 90 & 99 & 109 \\
\hline Payments & 20 & 30 & 32 & 42 \\
\hline Portfolio income, net & -41 & -53 & -64 & -82 \\
\hline Receipts & 84 & 107 & 108 & 127 \\
\hline Payments & 125 & 160 & 171 & 209 \\
\hline
\end{tabular}

SoURCE. U.S. Department of Commerce, Bureau of Economic Analysis, U.S. international transactions accounts.

nomic growth in many of the countries where the United States has substantial investments and continued large additions to holdings by U.S. investors. Direct investment receipts have tended to increase along with the growth of U.S. investments (chart 8), although they have varied with economic conditions abroad. Economic growth was strong in Latin America, Canada, and Western Europe in 1997, areas that account for the largest shares of U.S. direct investment abroad (table 10). In contrast, economic growth in Japan was anemic, and growth in the Asian developing economies fell sharply toward the end of the year. However, these Asian economies (including Japan) accounted for less than 15 percent of the stock of U.S. direct investment abroad at the end of 1996. Whereas income on investments in these Asian economies declined, particularly in the last half of 1997, favorable developments in the rest of the world kept receipts on direct investment up for the year.

Payments on foreign direct investment in the United States also increased substantially in 1997 as

8. U.S. direct investment abroad: Position and receipts, 1980-97

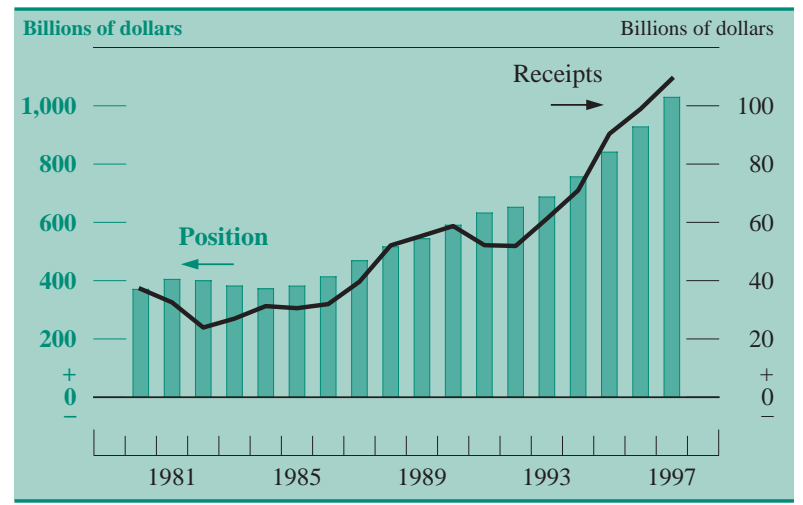

Note. The position for each year is the average of the year-end position for the current and previous years valued at current cost. The year-end position for 1997 was constructed by adding the recorded direct investment flows during 1997 to the recorded year-end position for 1996.

SourCE. U.S. Department of Commerce, Bureau of Economic Analysis; and Federal Reserve Board. 
10. U.S. direct investment position abroad, by area, year-end 1996

\begin{tabular}{|c|c|c|}
\hline Item & $\begin{array}{l}\text { Billions of } \\
\text { U.S. dollars }\end{array}$ & Percent \\
\hline Total & 796.5 & 100 \\
\hline Canada & 91.6 & 11 \\
\hline Europe & 399.6 & 50 \\
\hline United Kingdom & 142.6 & 18 \\
\hline $\begin{array}{l}\text { Latin America and } \\
\text { the Caribbean }\end{array}$ & 144.2 & 18 \\
\hline Asia & 106.1 & 13 \\
\hline Japan & 39.6 & 5 \\
\hline Other Asia ... & 66.5 & 8 \\
\hline Australia and New Zealand & 34.3 & 4 \\
\hline Other & 20.7 & 3 \\
\hline
\end{tabular}

Note. Valued at historical cost.

Source. Department of Commerce, Bureau of Economic Analysis.

a result of strong U.S. growth and high corporate profits. Direct investment payments have not always kept pace with the growth of foreign direct investment in the United States; between 1980 and 1993 the direct investment position increased sharply, but payments showed no upward trend (chart 9).

The rate of return on foreign direct investment in the United States remains low by any measure-far below the rate of return earned by U.S. direct investors abroad. Three measures of rates of return can be calculated. In each measure (shown in table 11), receipts or payments reported by direct investors are divided by estimates of the value of direct investment assets outstanding during the year. Historical cost is the price at which the assets were purchased; current cost adjusts the historical accounting values for inventories and plant and equipment to reflect movements in current replacement cost indexes; and market value adjusts the ownership position using general indexes of stock market prices. All attempts to
9. Foreign direct investment in the United States: Position and payments, 1980-97

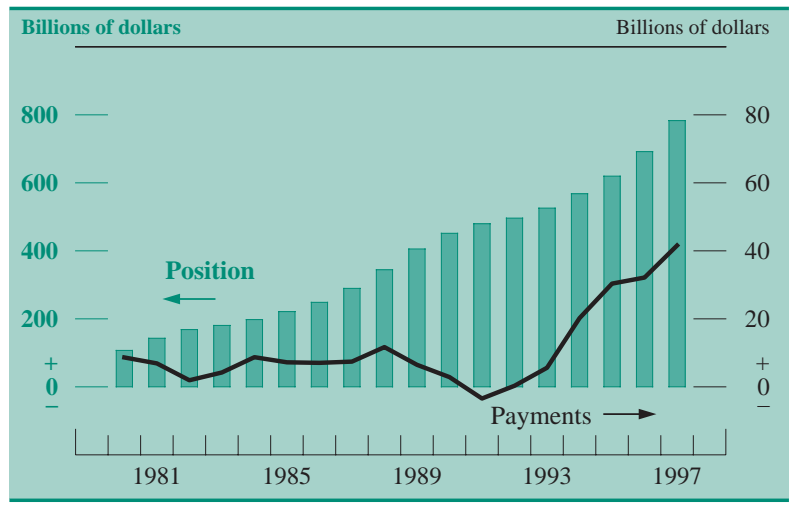

Note. See note to chart 8 .

SourCE. U.S. Department of Commerce, Bureau of Economic Analysis; and Federal Reserve Board.

estimate changes in the value of assets are imprecise and do not take into account developments that may be important to the value of specific investments.

As noted previously, the differential in rates of return between U.S. direct investment abroad and foreign direct investment in the United States has mitigated the effect of the negative U.S. net investment position on net investment income. Two important issues are whether these reported differentials are accurate and whether they are likely to persist. Numerous factors have probably contributed to the differential in reported rates of return. First, investments in many places overseas are more risky than investments in the United States, so some differential in rates of return should be expected. Moreover, many foreign investors who participated in the rapid increase in direct investment in the United States in the late 1980s had limited experience with foreign investments and made serious errors of judgment. Particularly ill-fated were Japanese investments in

11. Rates of return on direct investment, 1990-97

Percent

\begin{tabular}{|c|c|c|c|c|c|c|c|c|}
\hline Measure used in calculating the rate of return & 1990 & 1991 & 1992 & 1993 & 1994 & 1995 & 1996 & 1997 \\
\hline \multicolumn{9}{|l|}{ U.S. investment abroad } \\
\hline Historical cost ........ & 14.5 & 11.6 & 10.7 & 11.5 & 11.8 & 13.3 & 13.1 & 12.8 \\
\hline Current cost .. & 10.0 & 8.3 & 8.0 & 8.9 & 9.4 & 10.7 & 10.7 & 10.6 \\
\hline Market value & 7.5 & 6.7 & 6.4 & 6.7 & 6.7 & 7.6 & 6.9 & 6.9 \\
\hline \multicolumn{9}{|l|}{ Foreign investment in the United States } \\
\hline Historical cost ................... & .8 & -.8 & .1 & 1.3 & 4.2 & 5.7 & 5.4 & 6.1 \\
\hline Current cost $\ldots \ldots \ldots \ldots \ldots \ldots \ldots$. & 6 & -.7 & .1 & 1.1 & 3.5 & 4.9 & 4.6 & 5.3 \\
\hline Market value .... & .5 & -.6 & .0 & .8 & 2.6 & 3.4 & 2.8 & 3.2 \\
\hline
\end{tabular}

NoTE. The rates of return are calculated as follows: The numerator is direct investment receipts or payments, from the U.S. international transactions accounts. The denominator is the average of year-end figures for the current and previous year for the particular measure of the value of direct investment position shown. The positions for year-end 1997 are constructed by adding the recorded direct investment flows during 1997 to the recorded year-end positions for 1996.

For a discussion of the BEA's measure of "current cost" and "market value," see J. Steven Landefeld and Ann M. Lawson, "Valuation of the U.S. Net International Investment Position," Survey of Current Business, vol. 71 (May 1991), pp. 40-49.

SoURCE. U.S. Department of Commerce, Bureau of Economic Analysis, U.S. international transactions accounts and U.S. international investment position. 
U.S. commercial real estate. In addition, both U.S. and foreign corporations may succeed in using transfer prices to shift reported profits to countries with lower tax rates despite efforts by the Internal Revenue Service to limit this practice.

\section{Net Portfolio Investment Income}

Portfolio investment income consists of dividends and interest paid on a wide range of claims and liabilities. Receipts and payments are estimated by the Bureau of Economic Analysis (BEA) of the Department of Commerce based on estimates of holdings, dividend-payout ratios, and interest rates. Net portfolio income fell sharply in 1997, largely because of growing U.S. net international indebtedness (table 9). Over the past decade, the decline of net income has closely mirrored the growth of the negative net portfolio investment position (chart 10).

\section{Results of the Benchmark Survey of U.S. Ownership of Foreign Long-Term Securities}

The data on net portfolio investment income were revised in 1997 to take into account the newly available results of the Treasury Department's Benchmark Survey of U.S. Ownership of Foreign Long-Term Securities. These results indicated that official statistics had been significantly underestimating U.S. portfolio holdings of foreign equities and debt instruments with maturities longer than one year. As a result, the U.S. net international investment position was correspondingly less negative, and U.S. investment income slightly larger, than previously indicated.
10. Net portfolio investment: Position and income, 1980-97

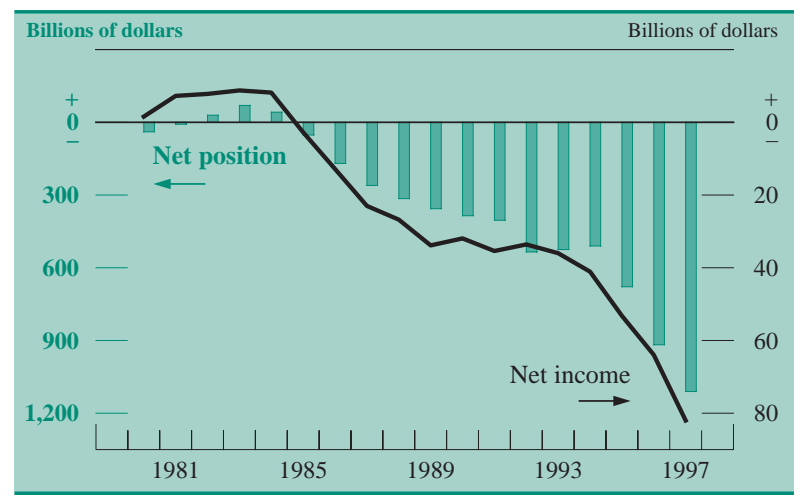

NOTE. The net position for each year is the average of year-end positions for the current and previous years. The year-end position for 1997 was constructed by adding the recorded net portfolio investment flows during 1997 to the recorded year-end position for 1996.

SourCE. U.S. Department of Commerce, Bureau of Economic Analysis; and Federal Reserve Board.

The survey was long overdue. The previous survey of U.S. holdings of foreign securities was conducted during World War II. The data on international capital flows that are gathered regularly by the Treasury International Capital (or TIC) Reports cover only purchases and sales of securities, not holdings. For the past fifty years, the BEA has had to rely on estimates of the value of U.S. holdings based on cumulative capital flows since World War II and estimates of changes in values. Estimates of holdings made by this method are likely to be increasingly inaccurate as time elapses.

The results of the recent survey indicate that, at the end of March 1994, U.S. residents held \$304 billion in foreign bonds and $\$ 567$ billion in foreign equities (table 12). Issuers from Canada and the other industrial countries accounted for most of the bonds held by U.S. residents. Holdings of bonds issued by developing countries were very small, except for those

12. U.S. long-term securities, by country of issuer, March 31, 1994

\begin{tabular}{|c|c|c|c|c|c|c|}
\hline \multirow{2}{*}{ Country or area } & \multicolumn{2}{|c|}{ Bonds } & \multicolumn{2}{|c|}{ Equities } & \multicolumn{2}{|c|}{ All securities } \\
\hline & $\begin{array}{l}\text { Billions of } \\
\text { U.S. dollars }\end{array}$ & Percent & $\begin{array}{l}\text { Billions of } \\
\text { U.S. dollars }\end{array}$ & Percent & $\begin{array}{l}\text { Billions of } \\
\text { U.S. dollars }\end{array}$ & Percent \\
\hline Total & 304 & 100 & 567 & 100 & 870 & 100 \\
\hline Canada & 68 & 23 & 40 & 7 & 108 & 12 \\
\hline Europe . & 129 & 42 & 270 & 48 & 399 & 46 \\
\hline United Kingdom & 20 & 7 & 100 & 18 & 120 & 14 \\
\hline Latin America & 34 & 11 & 57 & 10 & 92 & 11 \\
\hline Caribbean .... & 8 & 3 & 23 & 4 & 31 & 4 \\
\hline Asia & 40 & 13 & 151 & 27 & 191 & 22 \\
\hline Japan & 32 & 10 & 99 & 18 & 131 & 15 \\
\hline Other Asia & 9 & 3 & 51 & 9 & 60 & 7 \\
\hline Australia & 10 & 3 & 17 & 3 & 27 & 3 \\
\hline Other .... & 14 & 4 & 9 & 2 & 23 & 3 \\
\hline
\end{tabular}

SouRCE. U.S. Department of the Treasury. 
issued by four Latin American countries: Mexico, Argentina, Venezuela, and Brazil. About half of the long-term debt securities were denominated in U.S. dollars. Much smaller shares were accounted for by the yen, deutsche mark, and Canadian dollar, and the rest was spread across a wide variety of currencies. However, these results are of limited use in assessing the exchange rate exposure of U.S. investors because exposures may be hedged. Analysis of bond holdings by sector of issuer indicates that governments and international organizations constituted the largest category by far, accounting for more than 60 percent of the total. About one-third of reported holdings involved bonds issued by foreigners in the United States.

Industrial countries also accounted for the bulk of U.S. holdings of foreign equities. Two countries, the United Kingdom and Japan, together accounted for more than one-third of total U.S. holdings. However, holdings of equities issued by entities in developing economies were not negligible. Both Mexico and Hong Kong were among the top ten issuers. More than one-fourth of U.S. holdings was accounted for by American Depository Receipts (ADRs)—stocks that were specifically marketed to U.S. investors.

Comparison of the benchmark survey results for the end of March 1994 with the BEA's earlier end-ofyear estimates for 1993 and 1994 indicate that the BEA had been underestimating U.S. holdings by substantial amounts (table 13). Possible explanations for these errors are numerous. First, TIC reporting of purchases and sales of securities may have contained errors and omissions. Over time, U.S. investors and their fund managers have increasingly transacted directly in foreign markets, thus bypassing the U.S. financial intermediaries that form the core of the TIC reporting system. To ensure adequate coverage, the TIC reporting system has had to continually expand its list of reporters, and at times, Treasury has been slow to do so. Even if the TIC Reports covered 95 percent of net purchases, the omitted investments would cumulate to substantial sums over an extended period.

13. U.S. holdings of foreign securities: Earlier BEA estimates and benchmark survey results, 1993-94 Billions of dollars

\begin{tabular}{|c|c|c|c|}
\hline \multirow{2}{*}{ Item } & \multicolumn{2}{|c|}{$\begin{array}{l}\text { Earlier BEA estimates, } \\
\text { year-end }\end{array}$} & \multirow{2}{*}{$\begin{array}{c}\text { Benchmark } \\
\text { survey results } \\
\text { end of } \\
\text { March } 1994\end{array}$} \\
\hline & 1993 & 1994 & \\
\hline All foreign securities & 551 & 556 & 870 \\
\hline $\begin{array}{l}\text { Bonds } \\
\text { Equities }\end{array}$ & $\begin{array}{l}248 \\
303\end{array}$ & $\begin{array}{l}232 \\
324\end{array}$ & $\begin{array}{l}304 \\
567\end{array}$ \\
\hline
\end{tabular}

SOURCE. U.S. Department of Commerce and Department of the Treasury.
Second, the BEA's estimate of price changes may be inaccurate because the TIC Reports do not provide adequate information to identify with certainty the country of issue, currency, or term of the securities purchased. Moreover, the weights of various equities in U.S. portfolios may not mirror stock market price indexes that are readily available and used by the BEA.

The BEA raised its estimates of U.S. holdings of foreign securities at the end of 1994 more than $\$ 330$ billion (about 60 percent) in light of the results of the benchmark survey. The BEA also revised its estimates of U.S. holdings from 1985 forward. The revisions to holdings of equities were much larger (both in dollar and percentage terms) than the revisions to holdings of bonds. Moreover, the benchmark survey results indicate that the BEA's methodology had produced large errors in the estimated distribution of bond holdings by country and currency. In particular, holdings of Japanese bonds were much larger than estimated, as were holdings of foreigncurrency-denominated bonds.

Both the revision to the level of holdings and the change in composition had implications for the BEA's estimates of investment income for the period 1985 to the present. The BEA's revisions to investment income receipts in 1994 as a result of the benchmark survey amounted to an increase of about $\$ 10$ billion. The revision to income was small relative to the revision to holdings for two reasons. First, the bulk of the revision in the estimated position involved estimated holdings of equities, and dividend-payout ratios for foreign stocks tend to be low. (Capital gains are excluded from investment income in these accounts.) Second, the survey indicated larger holdings of foreign-currencydenominated bonds than the BEA had previously estimated, particularly low-yielding, yendenominated bonds.

The BEA made no revisions to the published data on capital flows as a result of the benchmark survey. The BEA could not determine whether the errors in the estimates of holdings were the result of unreported net purchases of foreign securities or errors in its estimates of valuation changes over the previous half a century; moreover, the BEA had no basis for determining the dates of unreported securities transactions.

\section{CAPITAL ACCOUNT TRANSACTIONS}

Foreign ownership of assets in the United States and U.S. ownership of assets abroad both rose signifi- 
cantly in 1997, an increase reflecting the continuing trend toward the globalization of financial markets as well as goods markets. Direct investment flows (both inward and outward) and private purchases of U.S. securities were particularly strong. Evidence of the gathering financial storm in Asia was apparent in U.S. capital flows mainly during the last quarter.

In 1997, in contrast to earlier years, increases in foreign official holdings in the United States did not play a major role in the capital flows that are the counterpart to the current account deficit (table 14). Foreign official assets in the United States rose $\$ 45$ billion in the first three quarters of 1997, below the pace for 1996; the increases were concentrated in the assets of certain industrial countries and members of OPEC. In the fourth quarter, foreign official assets declined sharply; the declines were concentrated in assets of Asian countries and of several developing countries outside Asia that were experiencing exchange market pressures. For the year as a whole, foreign official holdings in the United States rose only $\$ 18$ billion.

In contrast, increases in the assets of other foreigners in the United States in 1997 about equaled or surpassed previous records. Net purchases of U.S. stocks were particularly strong-a record $\$ 67$ billion. Net purchases of U.S. Treasury bonds by private foreigners remained robust; more than $\$ 30$ billion of U.S. Treasury securities were purchased in October alone, when developments in Asia led to a flight to quality. As the end of the year approached, however, some foreign private holdings of U.S. Treasury securities were liquidated. In addition, foreign direct investment in the United States amounted to a new high of $\$ 108$ billion, as the strong pace of mergers and acquisitions across national borders continued.

U.S. direct investment abroad in 1997 also reached a record net outflow- $\$ 119$ billion. U.S. net purchases of foreign securities in the first three quarters were $\$ 76$ billion, a little below the pace for 1996; however, net purchases fell sharply in the fourth quarter, probably in reaction to the perceptions of higher risk arising from financial turmoil in Asia. Banks in the United States reported a large increase in net claims on foreigners in the first three quarters of the year, but these outflows were largely reversed toward the end of the year.

With net recorded capital inflows to the United States exceeding the large U.S. current account deficit in 1997, the U.S. international accounts recorded a large negative statistical discrepancy for the second year in a row (table 14). This negative discrepancy indicates that net payments in the current account or net outflows in the capital account have been unrecorded. For example, illegal drug imports would contribute to a negative discrepancy, as would unrecorded investments abroad by U.S. residents or overstated capital inflows. Although the statistical discrepancy in the U.S. accounts tended to be positive in the years before 1990, large negative discrepancies have become more common since then for reasons that are not well understood.

14. Composition of U.S. capital flows, 1993-97

Billions of dollars

\begin{tabular}{|c|c|c|c|c|c|c|}
\hline Item & 1993 & 1994 & 1995 & 1996 & 1997 & $\begin{array}{l}\text { Change, } \\
1996 \text { to } 1997\end{array}$ \\
\hline Current account balance . & -91 & -134 & -129 & -148 & -166 & -18 \\
\hline Official capital, net & 70 & 45 & 100 & 128 & 17 & -111 \\
\hline Foreign official assets in the United States & 72 & 40 & 111 & 122 & 18 & -104 \\
\hline U.S. official reserve assets ............ & -1 & 5 & -10 & 7 & -1 & -8 \\
\hline Other U.S. government assets & 0 & 0 & -1 & -1 & 0 & 1 \\
\hline Private capital, net & 15 & 91 & 44 & 67 & 246 & 179 \\
\hline Net inflows reported by U.S. banking offices & 56 & 100 & -45 & -88 & -9 & 79 \\
\hline Securities transactions, net $\ldots \ldots \ldots \ldots \ldots \ldots \ldots$ & -44 & 31 & 95 & 181 & 273 & 92 \\
\hline Private foreign net purchases of U.S. securities & 102 & 91 & 196 & 290 & 352 & 62 \\
\hline Treasury securities .................... & 24 & 34 & 100 & 156 & 163 & 7 \\
\hline Corporate and other bonds & 59 & 54 & 82 & 121 & 122 & 1 \\
\hline Corporate stocks .......... & 19 & 3 & 14 & 13 & 67 & 54 \\
\hline U.S. net purchases of foreign securities & -146 & -60 & -100 & -108 & -79 & 29 \\
\hline Stocks $\ldots \ldots \ldots \ldots \ldots \ldots \ldots \ldots \ldots$ & -63 & -48 & -50 & -59 & -38 & 21 \\
\hline Bonds $\ldots \ldots \ldots \ldots \ldots$ & -83 & -12 & -50 & -49 & -41 & 8 \\
\hline Direct investment, net & -27 & -24 & -19 & -11 & -12 & -1 \\
\hline Foreign direct investment in the United States. & 49 & 46 & 68 & 77 & 108 & 31 \\
\hline U.S. direct investment abroad ............... & -76 & -69 & -87 & -88 & -119 & -31 \\
\hline Foreign holdings of U.S. currency $\ldots \ldots \ldots \ldots$ & 19 & 23 & 12 & 17 & 25 & 7 \\
\hline Other $\ldots \ldots \ldots \ldots \ldots \ldots \ldots \ldots \ldots$ & 11 & -39 & 0 & -32 & -32 & 0 \\
\hline Statistical discrepancy . & 6 & -3 & -15 & -47 & -97 & -50 \\
\hline
\end{tabular}

SourCE. U.S. Department of Commerce, Bureau of Economic Analysis, U.S. international transactions accounts. 


\section{PROSPECTS FOR 1998}

The fallout from the Asian crises is likely to have further consequences for U.S. international transactions in 1998. Until the economies of the countries directly affected begin to rebound, U.S. transactions with them, including exports of goods and services and the profits of direct investors, are likely to be depressed. The negative ramifications of the Asian crises for other trading partners may depress their demand for U.S. exports as well. The recent appreciation of the dollar and the associated loss in competitiveness of U.S. goods and services is also likely to continue to have a negative effect on the U.S. trade balance in 1998. On the other hand, continued strong growth in Latin America, Canada, and Western Europe, which account for the bulk of U.S. exports and direct investment, would tend to counteract the negative repercussions of Asian developments. 